\title{
Correction to: An epigenetic association of malformations, adverse reproductive outcomes, and fetal origins hypothesis related effects
}

\author{
Mark Lubinsky ${ }^{1}$
}

Published online: 2 June 2018

(C) Springer Science+Business Media, LLC, part of Springer Nature 2018

Correction to: Journal of Assisted Reproduction and Genetics (2018)

https://doi.org/10.1007/s10815-018-1197-2

The original version of this article unfortunately contained a mistake. The last 3 words of the article title were omitted. With this, the original article was corrected and the correct article title is now presented in here.

The online version of the original article can be found at https://doi.org/ 10.1007/s10815-018-1197-2

\footnotetext{
Mark Lubinsky

mlubinsky@wi.rr.com

16003 W. Washington Blvd., Wauwatosa, WI 53213, USA
} 